\title{
Digital Textbook: A State of the Art Resource to Increase Learners' Achievement
}

\author{
Maria Puspa Sari \& Armi Antasari \\ Akamigas Polytechnic of Palembang \\ E-mail:mariapuspasari@pap.ac.id; armi@pap.ac.id
}

\begin{abstract}
How to cite (in APA Style): Sari, M.P., \& Antasari, A. (2020). Digital textbook: a state of art resource to increase learners' achievement. Jurnal Pendidikan Bahasa dan Sastra, Vol. 20(2), 167-176. doi: https://doi.org/10.17509/bs_jpbsp.v20i2.33057
\end{abstract}

Article History: (Received: 25 Oct 2019, Revised: 1 May 2020, Accepted: 1 July 2020)

Journal homepage: http://ejournal.upi.edu./index.php/BS_JPBSP

\begin{abstract}
Technology has triggered the appearance of digital textbook in education especially in English. Digital textbook is an electronic version of printed books which has been popular in education. Several related studies had confirmed the advantages of using digital textbook for ESL learners. This study was conducted to explore the effectiveness of digital textbook in increasing learners' proficiency in English. The study with fifty seven participants was a true experimental research which applied pretest-posttest control group design. Having two groups of participants (experimental and control), this research was conducted by selecting the participants randomly, administering pretest, giving treatment, administering posttest, analyzing the data and interpreting the results. This research found that even though data was not normally distributed, the data still had the same variances. Therefore, the independent t-test in this research used Wilcoxon Signed Rank Test. The results discovered that the $t$ value was 0.30 which was lower than 0.050 . It indicated that the treatment was significantly effective in this research. In other words, this research revealed that digital textbook had contributed positively to the learners' English achievement as it was seen from the better performance of the experimental group than the control group.
\end{abstract}

Keywords: digital textbook; English proficiency; ESL Learners

\section{Buku Teks Digital: Sumber Bahan Ajar Mutakhir untuk Meningkatkan Prestasi Pembelajar}

\begin{abstract}
Abstrak: Teknologi telah memicu munculnya buku teks digital dalam dunia pendidikan khususnya dalam bahasa Inggris. Buku teks digital merupakan buku cetak versi elektronik yang populer di dunia pendidikan. Beberapa studi terkait telah mengkonfirmasi keuntungan menggunakan buku teks digital bagi pembelajar ESL. Penelitian ini dilakukan untuk mengeksplorasi keefektifan buku teks digital dalam meningkatkan kemampuan bahasa Inggris pembelajar. Penelitian dengan lima puluh tujuh partisipan merupakan penelitian eksperimental murni yang menerapkan desain kelompok kontrol pretest-posttest. Memiliki dua kelompok partisipan (eksperimen dan kontrol), penelitian ini dilakukan dengan memilih partisipan secara acak, pemberian pretest, pemberian perlakuan, pemberian posttest, analisis data dan interpretasi hasil. Hasil penelitian ini menunjukkan bahwa meskipun data tidak berdistribusi normal, namun datanya masih memiliki varian yang sama. Oleh karena itu, uji-t independen dalam penelitian ini menggunakan Wilcoxon Signed Rank. Test. Hasil penelitian menunjukkan bahwa nilai t sebesar 0,30 lebih rendah dari 0,050. Hal ni menunjukkan bahwa perlakuan pembelajaran secara signifikan efektif dalam penelitian ini. Dengan kata lain, penelitian ini mengungkapkan bahwa buku teks digital telah memberikan kontribusi positif terhadap prestasi belajar bahasa Inggris pembelajar yang terlihat dari kinerja kelompok eksperimen yang lebih baik daripada kelompok kontrol.
\end{abstract}

Kata kunci: Buku teks digital; kemahiran berbahasa Inggris; pembelajar ESL 


\section{INTRODUCTION}

Textbook has helped learners and teachers in the classroom; it provides a set of structured content completed with exercise and test and also saves teachers' time and effort for preparing teaching materials (Charalambous, 2011; Richards, 2015). As technology has come along and made huge change in education especially in English Language Teaching (ELT), the development of technology has resulted on the development of textbook. The existence of e-book which is the electronic version of paper book has stimulated the development of textbook. Some publishers have excelled their work by also completing their textbook with the interactive version of their textbook.

Digital textbook or sometimes called as interactive textbook refers to the electronic version of paper textbook which can be opened on a computer, laptop, mobile phone or a tablet (Blazer, 2013). Some interactive textbooks are just the PDF version of paper book or usually known as ebook, in form of application which is developed by platform such as Smartbok and Skills, and digital version of paper textbook which is completed with CD-ROM to install the digital textbook application (Blazer, 2013; Murray \& Perez, 2011; Ødegård, 2017). Thus, this study will explore the effectiveness of interactive textbook installed from a CDROM from the paper book. This kind of interactive textbook installed from the CDROM contains the material just like in the paper book. This digital version enables learners to listen to audio, watch video, play games, quizzes, see dictionary and get language information just by clicking the options on the screen (Mitsikopoulou, 2014, p. 411; Murray \& Perez, 2011). Some researchers have revealed some results from their studies focusing on the use of digital textbook in ELT. Bikowski and Casal (2018) found that all participants felt very satisfied with the digital textbook and it is highly recommended for English learning. There are some advantages of digital textbook. First, digital textbook can increase flexibility and learner control, motivation, interest, learning experience and convenience
(Bikowski \& Casal, 2018). With the interactive textbook installed in their laptop or computer, learners can also save their learning time and effort to bring the paper book (Blazer, 2013). On the other side, Blazer (2013) also explains that digital textbook is not effective for reading as learners found slower while reading. Also, digital textbook can retains learners in focusing on the content of their book especially for detail information.

In term of exploring digital textbook effect, most recent researches focused on the determining learners and teachers' perspective over the use of digital textbook without measuring how effective the digital textbook is for learners' proficiency (Murray \& Perez, 11), p. 52). To fill this gap, this study, therefore, aims to explore how effective the digital textbook is for increasing EFL learners' English proficiency. The reason of why this study brings important mission is because most advanced countries have made digital textbook as their national educational program while, in Indonesia, textbook is still considered 'rare'.

In this research, the role of the newest form of textbook was explored. This was initiated by the potential advantages for learners, teachers and institution. Textbook as one of main sources in learning holds very essential role.

Textbook is an important part of a course. It is one of main resources for learners. Textbook is a standardized book used in a course, class, colleges or schools as a main source of information both for teachers and learners (Graves, 2000; Hornby, 2006; Richards, 2015). A standardized textbook usually includes syllabus, instructions, various learning resources, language model and maintained quality (Richards, 2015). With those contents, it helps teachers in teaching and even benefits new teachers as textbook is usually in a form of structured materials which offer some teaching orientation and guidance (Gak, 2011). In ELT, textbook even plays as a window of English-speaking country as EFL textbooks include the culture of western and authentic language model for learners (Radić- 
Bojanić \& Topalov, 2016). So far, textbook design and content have developed to keep up with the advancement of technology and learners' modern life.

Nowadays, the form of textbook is becoming more modern by having electronic version or e-book and even textbooks can be found in form of digital or usually called as digital or interactive textbook. If e-book refers to the electronic version which is exactly the same as the paper version, digital textbook refers to an electronic learning resource which allows users to access its audio, video, language information and all kinds of interactive contents by just clicking the buttons (Fernandes, 2012, p. 3194; Murray \& Perez, 2011). Digital textbook initiative has started in the USA for two decades and it started from $\mathrm{CD}$ and now digital textbooks can be accessed through online (Fernandes, 2012). Many platforms produce interactive textbooks with various purposes, interactive content and features. There are some advantages of this new version of textbook. First of all, it is environmentally friendly as it does not use paper as materials, so it cost less than the paper one and reduce learners' effort to bring heavy bags to colleges (Blazer, 2013; Fernandes, 2012, p. 50). Its' interactive features which enable learners to watch, video, listen to audio, etc. can increase learning experience (Blazer, 2013; Bikowski \& Casal, 2018). Then, it can also increase learners' engagement, satisfaction, participation and convenience in learning as well as their technology literacy (Bikowski \& Casal, 2018). Therefore, it is not surprising when many advanced countries consider digital textbook as the new trend in education and decide to make a national program to accommodate this trend.

Nowadays, there are some formats of digital or interactive textbook which is widely known especially in advanced countries. At the beginning of last decade, the very first form of electronic book appeared in form of pdf document which is the scanned form of the printed version (Mitsikopoulou, 2014). Recent years, the form of textbook has been more modern. The new form of textbook is digital textbook application which must be installed from the CD ROM of the paper book. Publishers completed their printed book with CD or DVD which enable their users to install the application of their digital textbook (Odegard, 2017). Finally, the latest version of textbook is in form of application on computer, tablet even a smartphone which can be downloaded and used both offline and online (Bikowski \& Casal, 2018; Fernandes, 2012; Odegard, 2017).

This new trend in education especially English language teaching has attracted many publishers and platforms to develop their products and compete across the globe. According to Fernandes (2012, p. 3193), at the beginning of this trend, the United States started in the last decades by facilitating schools with computers and internet. Since then, digital textbook has become more popular as it offers potential benefits and profit. Fernandes (2012) compares some digital textbook from various publishers and platforms such as Apple iBooks, Barnes \& Noble NOOK Study, CafeScribe, Cengage MindTap, Cengage YouBook, CourseSmart, DynamicBooks, Flat World Knowledge (MIYO, Ingram Vitalsource, McGraw-Hill Create and Connect, Pageburst, Pearson MyLab, Wikibooks, Xplana and eReader. All those digital textbooks can be accessed online and offline through computer, tablet and smartphone; their digital textbook cover basic features such as highlighting, note taking, color tags and bookmark. However, they have different unique features as their strategy to attract users such as Apple iBooks with its $3 \mathrm{D}$ animations, videos and interactive illustrations, Barnes \& Noble NOOK Study with its dual book view, instructors' guide and dictionary, CafeScribe with its reading communities, DynamicBooks with its online tests, instructors and animation, and Pearson MyLab with its text-to-speech and LMS integration. So, the development of electronic textbook has arrived at the stage of digital or interactive textbooks which are available both online and offline. Those digital textbooks can be accessed by just buying their application online, license via 
credit card and installing their application from DVD or CD ROM.

\section{METHOD}

This initial study was an experimental study aiming to determine the effectiveness of digital textbook on learners' English performance. The population of this study was students at Polytechnic of Akamigas Palembang. The digital textbook used in this study was SpeakOut Second Edition published by Pearson Longman. This book was issued in two versions; printed and digital textbook. The digital textbook called as ActiveTeach must be installed from the CD ROM. The digital textbook has some features such as answers to exercises, audio, integrated video, shortcuts to relevant pages of grammar lesson and pictures with vocabulary, extra worksheets, tests, English games, keyboard, phonetic keyboard, stopwatch and scoreboard (Carr \& Maguire, 2012). There was one instrument used in this study; the English test. The English test will be taken from the Pearson Longman Placement Test. From this test, it would be discovered if learners' English proficiency level increased or not after the treatment.

\section{Research design}

As this research's purpose was to find out if the use of digital textbook was effective to boost learners' English proficiency, this research was conducted by doing experiment to two groups of participants.

This research used a true experimental design using the pretestposttest control group design. This research was conducted in several stages. The first one was participant selection; there were two classes selected randomly as the participants of this study and they were assigned as experimental and control group. The experimental group received the treatment, i.e. learning using the chosen digital textbook. The group was taught by one lecturer in 16 meetings including pre-test and post-test. After the treatment finished, the data collected from the participants' pre-test and post-test scores were calculated and analyzed using t-test. In analyzing the participants' scores, firstly, the paired sample t-test was conducted to figure out if the experimental group's posttest scores were better than their pretest scores. After that, the independent ttest was conducted to compare the post-test performance of the experimental and control group. This was to find out if the digital textbook was effective to increase learners' English achievement.

\section{Participants}

This study involved fifty seven participants in a private college in Palembang. All of them were English learners in an engineering college, Akamigas Polytechnic of Palembang. At the time of the treatment, they were in the first year of studying. These participants were selected randomly as a true experimental design requires random sampling method. They were then assigned into two groups; experimental and control groups. The experimental group consisted of 32 participants while the control group had 25 participants.

\section{Data collection and analysis}

The data were collected from the pretest and posttest in this research. After collecting the data, data analysis was conducted. The data analyses in this research were normality test, homogeneity test, paired sample t-test and independent t-test. At the beginning, the normality test was conducted to find out if the data was normal. After that the homogeneity test was also carried out to find out if the data had the same variance. Then, paired t-test was done to find out if there was significant difference between the pretest and posttest in the experimental group. Finally, the independent t-test was conducted to compare the performance between experimental and control group.

This research also involved two researchers; chief and member of researcher. Both of researchers were lecturers in the college teaching language. The chief researcher was responsible for designing the research, determining the participant selection, conducting the treatment and interpreting the results of the research. Meanwhile, the member was responsible for 
conducting the pretest and posttest, analyzing the data and presenting the data.

\section{RESULTS AND DISCUSSION}

In this study, there were pre-test and posttest given to 57 participants; 32 participants in experimental group and 25 participants in control group. After conducting the tests and treatment, it was found that the two groups performed differently. Overall, experimental group performed better achievement rather than the control group. The detail explanation would be further described in the following section.

\section{The Experimental Group}

In the experimental group, 32 participants took part in pre-test, treatment and post-test. These participants were asked to follow the treatment until it was finished.

In the pre-test, the average score was 80, the highest score was 97 and the lowest score was 64 . After having the pre-test, the participants continued getting the treatment. The treatment was being taught English using the digital textbook for several regular meetings. When the treatment finished, the participants were then given post-test. The post-test results were then calculated and increase was found; the average score was 86, the highest score was 100 and the lowest was 60.

Based on the results, it can be concluded that from their pre-test and post- test, participants in the experimental group indicated a positive trend by having increasing achievement.

\section{The Control Group}

Unlike experimental group which consisted of 32 participants, the control group only had 25 participants taking part in pre-test and post-test.

In the pre-test, the average score was 77 , the highest score was 97 and the lowest score was 62 . The post-test results were then calculated and increase was found; the average score was 80 , the highest score was 92 and the lowest was 64.

Based on the results, it can be concluded that from their pre-test and posttest, participants in the control group indicated a positive trend by having increasing achievement. However, based on the calculation, the experimental group performed slightly better than control group.

\section{The Normality Test and Homogeneity Test}

Normality test was required when a ttest analysis would be done. It aimed to ensure that the data was normally distributed. In this research, before analyzing the data to gain the paired and independent t-test, the normality test was carried out first. The result of the normality test for the experimental group is as follow:

Table 1. Tests of Normality for Experimental Group

\begin{tabular}{|c|c|c|c|c|c|c|c|}
\hline & \multirow[b]{2}{*}{ Experimental } & \multicolumn{3}{|c|}{ Kolmogorov-Smirnov $^{a}$} & \multicolumn{3}{|c|}{ Shapiro-Wilk } \\
\hline & & Statistic & $\mathrm{df}$ & Sig. & Statistic & $\mathrm{df}$ & Sig. \\
\hline Score & Pretest & 085 & 32 & $200^{*}$ & 970 & 32 & ,495 \\
\hline & Postest & 197 & 32 & ,003 & 866 & 32 & ,001 \\
\hline
\end{tabular}

*. This is a lower bound of the true significance.

a. Lilliefors Significance Correction

Based on the table, the significant value for the pretest was 0.495 and for the posttest was 0.001 . Thus, the pretest data was normally distributed, but the posttest data was otherwise. Here is the homogeneity test result for experimental group: 
Table 2. Test of Homogeneity of Variance

\begin{tabular}{|ll|l|l|l|l|}
\hline & $\begin{array}{l}\text { Levene } \\
\text { Statistic }\end{array}$ & df1 & df2 & Sig. \\
\hline Score & Based on Mean & 13,363 & 1 & 62 &, 001 \\
& Based on Median & 5,755 & 1 & 62 &, 019 \\
& $\begin{array}{l}\text { Based on Median and } \\
\text { with adjusted df }\end{array}$ & 5,755 & 1 & 48,608 &, 020 \\
Based on trimmed mean & 12,201 & 1 & 62 &, 001 \\
\hline
\end{tabular}

The table revealed that the significant value based on Mean was 0.001 . This means that the data was not equal. The data of the experimental, in conclusion, revealed two facts. The first is that the data of experimental group posttest was not normal even though the pretest was normal. The second was that the experimental group data did not have the same variance. The data from control group was also calculated to see its normality and homogeneity. Here is the result:

Table 3. Tests of Normality

\begin{tabular}{|l|l|l|l|l|l|l|l|}
\hline & \multirow{3}{*}{} & \multicolumn{5}{|l|}{ Kolmogorov-Smirnov ${ }^{\mathrm{a}}$} & \multicolumn{3}{l|}{ Shapiro-Wilk } \\
\cline { 3 - 8 } & Control & Statistic & $\mathrm{df}$ & Sig. & Statistic & df & Sig. \\
\hline Score & Pretest &, 155 & 25 &, 123 &, 955 & 25 &, 327 \\
& Postest &, 125 & 25 &, $200^{*}$ &, 967 & 25 &, 566 \\
\hline
\end{tabular}

*. This is a lower bound of the true significance.

a. Lilliefors Significance Correction

The table displayed the result of normality test for control group which was normally distributed. It could be seen from the sig. value of the pretest which was 0.327 and the posttest was 0.566. The result of homogeneity test is as follow:

Table 4. Test of Homogeneity of Variance

\begin{tabular}{|ll|l|l|l|l|}
\hline & $\begin{array}{l}\text { Levene } \\
\text { Statistic }\end{array}$ & df1 & df2 & Sig. \\
\hline Score & Based on Mean & 2,084 & 1 & 48 &, 155 \\
Based on Median & 1,284 & 1 & 48 &, 263 \\
Based on Median and & 1,284 & 1 & 42,123 &, 264 \\
with adjusted df & 2,037 & 1 & 48 &, 160 \\
Based on trimmed mean & 2,48 \\
\hline
\end{tabular}

Based on the table, the data of control group had the same variance as its value was 0.155 higher than the significance level 0.05. Thus, it could be said that the data of the control group was normally distributed and had same variance.

In conclusion, among all data of the two groups, the data of the experimental group was not normal and did not have the same variance. However, the show must go on. The data analysis would keep running by using nonparametric test which does not require normal distribution and homogeneity of data (Kaur and Kumar, 2015; Sprent and Smeeton, 2001)

The English Proficiency Difference between Digital and Non-Digital Textbook Class

In this phase, there were two data analysis accomplished; paired sample t-test and independent sample t-test. The paired sample test was to reveal the effectiveness if the treatment in the experimental group was effective while the independent t-test was to 
reveal the difference between the two different groups which were experimental and control group.

To conduct the paired sample test, normality test was conducted before and the result was that the data was not normally distributed. Therefore, in this analysis, nonparametric test was carried out. While parametric test requires normal distribution and equal variance, non-parametric test does not rely on the normality and homogeneity of the data (Kaur and Kumar, p. 339, 2015).

In this research, paired sample test used Wilcoxon Sign Rank Test computed by SPSS. The result of the test is as follow:

Table 5. Ranks

\begin{tabular}{|ll|r|r|r|}
\hline & & N & Mean Rank & Sum of Ranks \\
\hline Score - & Negative Ranks & $0^{\mathrm{a}}$ &, 00 &, 00 \\
Experimental & Positive Ranks & $64^{\mathrm{b}}$ & 32,50 & 2080,00 \\
& Ties & $0^{\mathrm{c}}$ & & \\
& Total & 64 & & \\
\hline
\end{tabular}

a. Score $<$ Experimental

b. Score $>$ Experimental

c. Score $=$ Experimental

The table reveals that all participants in the experimental group performed positive increase in their English achievement. It can be seen from the number of positive ranks which is 64 . Then the result of Wilcoxon test was:

Table 5. Test Statistics ${ }^{a}$

\begin{tabular}{|l|r|}
\hline & $\begin{array}{c}\text { Score - } \\
\text { Experimental }\end{array}$ \\
\hline $\begin{array}{l}\text { Z } \\
\text { Asymp. Sig. (2- } \\
\text { tailed) }\end{array}$ & $-6,956^{\mathrm{b}}$ \\
\hline
\end{tabular}

a. Wilcoxon Signed Ranks Test

b. Based on negative ranks.

Based on the result of the analysis, the sig. (2-tailed) value was 0.000 which was below the significance level 0.05 . This indicated that there was statistically significant difference in the experimental group. Therefore, the treatment in this group was considered successful or significantly effective in increasing the participants' score.
After comparing the scores of pretest and post-test of the experimental group, data analysis proceeded to calculate the difference of the post-test scores between experimental and control group. The result of the analysis is as follow:

Table 6. Ranks

\begin{tabular}{|l|l|r|r|r|}
\hline & Group & \multicolumn{1}{|c|}{ N } & Mean Rank & Sum of Ranks \\
\hline Posttest & Experimental & 32 & 33,22 & 1063,00 \\
& Control & 25 & 23,60 & 590,00 \\
& Total & 57 & & \\
\hline
\end{tabular}


The table shows that the mean rank of the experimental group was higher than the control group $(33.22>23.60)$. It was clearly proven that based on the mean rank, the experimental group performed better. However, deep analysis was still needed to find its significance and the result was:

Table 7. Test Statistics ${ }^{a}$

\begin{tabular}{|l|r|}
\hline & Posttest \\
\hline Mann-Whitney U & 265,000 \\
Wilcoxon W & 590,000 \\
Z & $-2,173$ \\
Asymp. Sig. (2- &, 030 \\
tailed) & \\
\hline
\end{tabular}

a. Grouping Variable: Group

The result of Mann Whitney $\mathrm{U}$ test revealed the sig. (2-tailed) value was 0.30 which was lower than 0.050. This fact indicated that the treatment was significantly effective in this research.

Based on the data explanation above, two results of the analysis were discovered. Based on the paired sample test, the treatment was significantly effective in the experimental group as the participants' score in the post-test were overall higher than their pre-test. Also, when the scores were compared to the scores from control group, the result remained the same indicating that the treatment in this research was statistically significantly effective in increasing the participants' scores.

\section{Discussion}

The results of data analysis clearly revealed that the utilization of digital textbook in English class was effective to boost learners' English proficiency. This finding confirmed the results of several previous researches which found that digital textbook was able to promote learners' affective skill and increase their achievement in learning (Choi, 2005, p. 4877; Pearson, 2014, p. 4; Rockinson-Szapkiw, Courduff, Carter, \& Bennett, 2013, p. 264). It was confirmed by learners' academic achievement result in those studies which indicated that learners' who used digital textbook performed better even much better than those who used the printed textbooks. Choi (2005) argues that digital textbook must be appropriate with the characteristics of the course or lesson. It is because each lesson has its own characteristics such as pronunciation and speaking lesson which would be better if the digital textbook includes audio as the model for learners. Also, adding some multimedia features would benefit the learners, for example adding audio or video. This is to provide authentic materials and experience for the students. Moreover, the digital textbook would be a lot better if it also include additional material where learners can shape their soft skills such problem solving, teamwork, etc.

Furthermore, Chau (2008, p. 4) discovered that the application of digital textbook could also develop learners' literacy and language development. RockinsonSzapkiw, et. al (2013, p. 260) argues that reading on digital textbook last consistently longer than on traditional or printed books. However, the development of technology enables developer to add rearrangeable text and features which then are expected to omit potential disadvantages of digital textbook.

Also, learners who used digital textbook are found to have better psychomotor and learn more effectively (Rockinson-Szapkiw, et. al (2013, p. 264). It is because when learners learn using digital textbook, they must interact by touching some buttons to play the features in the digital textbook. Reints (2015) explains that digital textbook not only enable learners to have visual experience but also audio and audiovisual experience. Then, digital textbook is also adaptable 
In addition, learners who learn using digital textbook indicate very positive attitude towards learning (Rockinson-Szapkiw, et. al (2013, p. 264). Therefore, when there is a statement that digital textbook can increase learners' achievement, it is very reasonable to believe as their positive attitude towards digital textbook affect their academic achievement. A study conducted by Torey Jones and Carol Brown (2011 cited in Regueira \& Rodríguez, 2015) tried to find out students preferences after doing treatment, giving them assignment using digital textbook and printed textbook, to the students. The results proved interesting fact that after having experience on learning with digital and printed textbook, learners tend to prefer the digital one because it provides the features of pronunciation, audio, etc. The students' preference might be affected by their familiarity with computers, tablets and smartphone as it is well known that those electronic devices are very popular among learners. Therefore, the use of digital textbook has very promising potentials not only for education due to the increasing digital interest across the globe (Misra, 2015).

Based on the explanation, the result of this study confirmed the previous studies which agree that using digital textbook in ESL classes can be very effective to increase learners' achievement. Furthermore, learners can develop their literacy and communication skill. Also, effective learning can be achieved through learning using digital textbook.

\section{CONCLUSION}

In conclusion, the utilization of the newest technology, in this case is digital textbook, has brought effective results. This research confirmed that using digital textbook was significantly effective to increase ESL learners' English achievement. This study was an initial study of a research project which has wider scope which however only tried to reveal if digital textbook was really effective for ESL classes. Following up this research, a study on exploring the attitudes of learners and teachers towards digital textbook will be relevant to conduct. Moreover, this study can be the reason of developing a digital textbook for ELT classes.

\section{ACKNOWLEDGMENTS}

The researchers would like to express their gratitude to the Ministry of Research and Higher Education of Republic of Indonesia for its full support on this research. .

\section{REFERENCES}

Bikowski, D. \& Casal, J. E. (2018). Interactive Digital textbook and engagement: A learning strategies framework. Language Learning \& Technology Journal, 22(1), 119136. ISSN 1094-3501. Retrieved from http://lltjournal.org//

Blazer, C. (2013). Literature Review: Digital Textbooks. Research Services of MiamiDade County Public Schools. Retrieved from http://drs.dadeschools.net//

Carr, J. C. \& Maguire G. (2012). Speak Out Starter Teacher's Resource Book. Essex: Pearson.

Charalambous, A. C. (2011). The role and use of course books in EFL. ERIC Joumal. Retrieved from http://files. eric.ed.gov//

Chau, M. (2008). The effects of electronic books designed for children in education. Design of Electronic Text, 1(1), 1-4. Retrieved from https://tspace.library.utoronto.ca

Choi, J. (2005). The effect of digital textbook on academic achievement in Korea. Journal of Theoretical and Applied Information Technology, 95(18), 48714878. ISSN: 1992-8645. Retrieved from www.jatit.org.

Fernandes, L. (2012). Digital textbook platforms: Trends and technologies. Proceeding of II Congresso Internacional TIC Educacao, 3191-3211. Retrieved from http://ticeduca.ie.ul.pt//

Gak, D.M. (2011). Textbook- An important Element in the teaching process. Fakultet tehničkih nauka - Engleski jezik, Novi Sad, 78-82. Retrieved from http://epub.ff.uns.ac.rs// 
Graves, K. (2000). Designing Language Course: A Guide for Teachers. Boston: Cengage Learning.

Hornby, A. S. (2006). Oxford Advanced Learners Dictionary (7th ed.). Oxford, UK: Oxford University Press.

Kaur, A. \& Kumar, R. (2015). Comparative analysis of parametric and nonparametric tests. Journal of Computer and Mathematical Sciences, 6(6), 336-342. ISSN 2319-8133 (Online). Retrieved from www.compath-journal.org.

MindCet. (2012). The future of digital textbooks. Ed-Tech innovation center. Retrieved from www.mindcet.org

Misra, P. K. (2015). Digital textbooks in India: Emergence, promotion and future predictions. In J. R. Rodriguez, E. Bruillard \& M. Horsley (eds.) Digital Textbooks: What's New?, 101-111. Universidade de Santiago de Compostela. Retrieved from www. http://laeremiddel.dk.

Mitsikopoulou, B. (2014). Digital enrichment of EFL textbooks. ResearchGate Journal, 404-430 Retrieved from https://www.researchgate.net/publica tion $/ 283290226$

Murray, M. C. \& Perez J. (2011). ETextbooks are coming: Are we ready? Informing Science and Information Technology Journal, 8: 49-60.Retrieved from http://digitalcommons.kennesaw.edu //

Ødegård, A. (2017). The use of digital textbooks in upper secondary school English classrooms in Norway. (Master's thesis). Retrieved from http://brage.bibsys.no//
Pearson Education. (2014). Monroe Township High School Case Study. Retrieved from www.pearsoned.com.

Radić-Bojanić, B.B. \& Topalov, J.P. (2016). Textbooks in the EFL Classroom: Defining, assessing and analyzing. Collection of Papers of the Faculty of Philosophy XLVI (3).University of Novi Sad DOI:10.5937/ZRFFP46-12094

Reints, A. J. C. (2015). How to learn from digital textbooks: Evaluating the quality. In J. R. Rodriguez, E. Bruillard \& M. Horsley (eds.) Digital Textbooks: What's New?, 204-224. Universidade de Santiago de Compostela. Retrieved from www. http://laeremiddel.dk

Regueira, N. R. \& Rodríguez, J. R. (2015). The digital textbook. A look at the current state of the art. In J. R. Rodriguez, E. Bruillard \& M. Horsley (eds.) Digital Textbooks: What's New?, 20-43. Universidade de Santiago de Compostela. Retrieved from www. http://laeremiddel.dk.

Richards, J. (2015). The Role of Textbooks in a Language Program. Retrieved from https://www.researchgate.net/publica tion $/ 265455920$

Rockinson- Szapkiw, A. J., Courduff, J., Carter, K., \& Bennett, D. (2013). Electronic versus traditional print textbooks: A comparison study on the influence of university students' learning. Computers \& Education, 63, 259-266. Retrieved from www.elsevier.com/locate/compedu

Sprent, P. \& Smeeton, N. C. (2001). Applied Nonparametric Statistical Method. Florida, USA: Chapman \& Hall/CRC 